\title{
Dyslipidemia aterogenna - nieklasyczny czynnik ryzyka incydentów sercowo-naczyniowych?
}

\author{
Atherogenic dyslipidemia - is it a non-classical risk factor \\ of cardiovascular disease?
}

\author{
Michał Łabuz ${ }^{1}$, Katarzyna Starzyk ${ }^{1}$, Beata Wożakowska-Kapłon ${ }^{1,2}$ \\ ${ }^{1}$ Klinika Kardiologii i Elektroterapii Świętokrzyskiego Centrum Kardiologii w Kielcach \\ ${ }^{2}$ Wydział Nauk o Zdrowiu Uniwersytetu Jana Kochanowskiego w Kielcach
}

\section{Streszczenie}

W niniejszej pracy zaprezentowano przypadek pacjenta z dyslipidemią aterogenną, u którego wystąpił kolejny incydent sercowo-naczyniowy, pomimo stosowanej terapii hipolipemizującej. Stanowi to przykład utrzymywania się ryzyka rezydualnego, nawet po osiągnięciu docelowych wartości cholesterolu frakcji LDL.

Słowa kluczowe: dyslipidemia aterogenna, ryzyko rezydualne

Folia Cardiologica 2017; 12, 1: 86-90

\section{Wstęp}

Choroby układu krążenia są najczęstszą przyczyną zgonów na świecie, w tym także w Polsce. W 2012 roku, zgodnie z danymi Światowej Organizacji Zdrowia (WHO, World Health Organization), śmiertelność z powodu incydentów sercowo-naczyniowych w Polsce wynosiła 323/100 000/rok, a przeciętna długość życia 77 lat [1]. Głównymi modyfikowalnymi czynnikami ryzyka chorób układu krążenia są nadciśnienie tętnicze, zaburzenia gospodarki lipidowej i węglowodanowej, nadwaga i otyłość, palenie tytoniu oraz złe nawyki żywieniowe, brak aktywności fizycznej i stres psychospołeczny [2]. Hipercholesterolemia pozostaje najczęściej występującym w populacji polskiej modyfikowalnym czynnikiem ryzyka chorób układu krążenia i toczy się dyskusja dotycząca wpływu hipertriglicerydemii oraz aterogennej dyslipidemii na proces powstawania miażdżycy [3].

\section{Opis przypadku}

W niniejszej pracy opisano przypadek 52-letniego mężczyzny leczonego w klinice kardiologii z powodu kolejnego zawału serca. U chorego stwierdzono nieprawidłową glikemię na czczo, otyłość (wskaźnik masy ciała [BMI, body mass index] 33,6 kg/m²) oraz aterogenną dyslipidemię (stężenie triglicerydów [TG] 342 mg/dl) i obniżone stężenie cholesterolu frakcji lipoprotein o wysokiej gęstości (HDL, high-density lipoprotein) (29 mg/dl). Stężenie cholesterolu związanego z cząsteczkami lipoprotein o niskiej gęstości (LDL, low-density lipoprotein) wynosiło 94 mg/dl (tab. 1). Funkcja nerek była prawidłowa - klirens kreatyniny obliczony według wzoru MDRD (Modification of Diet in Renal Disease) miał wartość $71,9 \mathrm{ml} / \mathrm{min}$.

W przeszłości chory 2-krotnie przebył zawał serca z uniesieniem odcinka ST (STEMI, ST-elevation myocardial infarction) ściany dolnej i przedniej oraz udar krwotoczny mózgu. Począwszy od pierwszego epizodu sercowo-naczyniowego, zalecano mu farmakologiczne i niefarmakologiczne metody prewencji wtórnej, tym niemniej, poza normalizacją wartości ciśnienia tętniczego, pozostałych celów terapii, w tym stężenia cholesterolu frakcji LDL, nie osiągnięto (ryc. 1). W wykonanym przy przyjęciu do kliniki elektrokardiograficznym (EKG) badaniu spoczynkowym stwierdzono cechy ostrego zawału 
Tabela 1. Wyniki lipidogramu i stężenia aminotransferazy alaninowej (AIAT, alanine aminotransferase) oraz leki hipolipemizujące przyjmowane w chwili badania u opisanego pacjenta

\begin{tabular}{lccc|}
\hline Oznaczany parametr & $\begin{array}{c}\text { Styczeń 2016 r. } \\
\text { (rosuwastatyna 10 mg) }\end{array}$ & $\begin{array}{c}\text { Lipiec 2016 r. } \\
\text { (rosuwastatyna 15 mg, } \\
\text { fenofibrat 215 mg) }\end{array}$ & $\begin{array}{c}\text { Listopad 2016 r. } \\
\text { (rosuwastatyna } 40 \text { mg, } \\
\text { fenofibrat 215 mg) }\end{array}$ \\
\hline Cholesterol całkowity [mg/dl] & 142 & 157 & 143 \\
Cholesterol frakcji HDL [mg/dl] & 29 & 29 & 30 \\
Cholesterol frakcji LDL [mg/dl] & 94 & 80 & 55 \\
Triglicerydy [mg/dl] & 342 & 243 & 294 \\
AIAT [j./l] & 177 & 25,8 & 34
\end{tabular}

HDL (high-density lipoprotein) - lipoproteiny o wysokiej gęstości; LDL (low-density lipoprotein) - lipoproteiny o niskiej gęstości

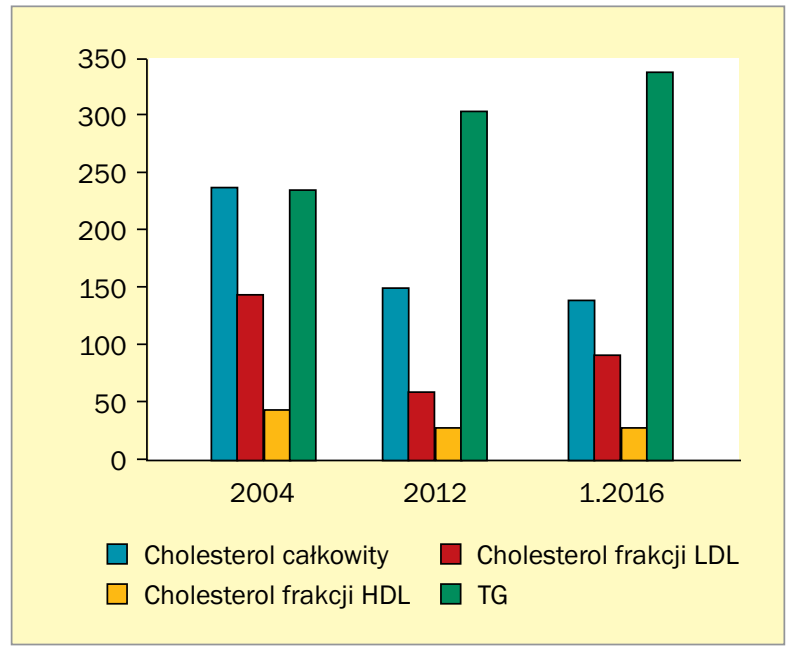

Rycina 1. Zmiany lipidogramu w okresie 12 lat u opisanego pacjenta; LDL (low-density lipoprotein) - lipoproteiny o niskiej gęstości; HDL (high-density lipoprotein) - lipoproteiny o wysokiej gęstości; TG - triglicerydy ściany przedniej (istotne uniesienie odcinka ST w odprowadzeniach V3-V6) (ryc. 2).

$\mathrm{U}$ chorego zastosowano kwas acetylosalicylowy w dawce nasycającej 300 mg, w kolejnych dobach 75 mg, tikagrelor w dawce $180 \mathrm{mg} /$ dobę, atorwastatynę w dawce $80 \mathrm{mg}$, pantoprazol w dawce $40 \mathrm{mg}$ oraz heparynę niefrakcjonowaną. W wykonanym przy przyjęciu badaniu echokardiograficznym stwierdzono akinezę koniuszka, przy zachowanej kurczliwości globalnej lewej komory serca (frakcja wyrzutowa [EF, ejection fraction] lewej komory wynosiła 50\%). W trybie pilnym wykonano koronarografię, uwidaczniając obraz skrzepliny zamykającej dystalny segment gałęzi międzykomorowej przedniej lewej tętnicy wieńcowej (LAD, left anterior descending). Wykonano przezskórną angioplastykę wieńcową (PCA, percutaneous coronary angioplasty) zamkniętej LAD, udrażniając ją prowadnikiem. Nie zobrazowano istotnych zmian w pozostałych naczyniach wieńcowych. W badaniach laboratoryjnych stwierdzono typową ewolucję stężenia troponiny T, potwierdzającą martwicę mięśnia sercowego.

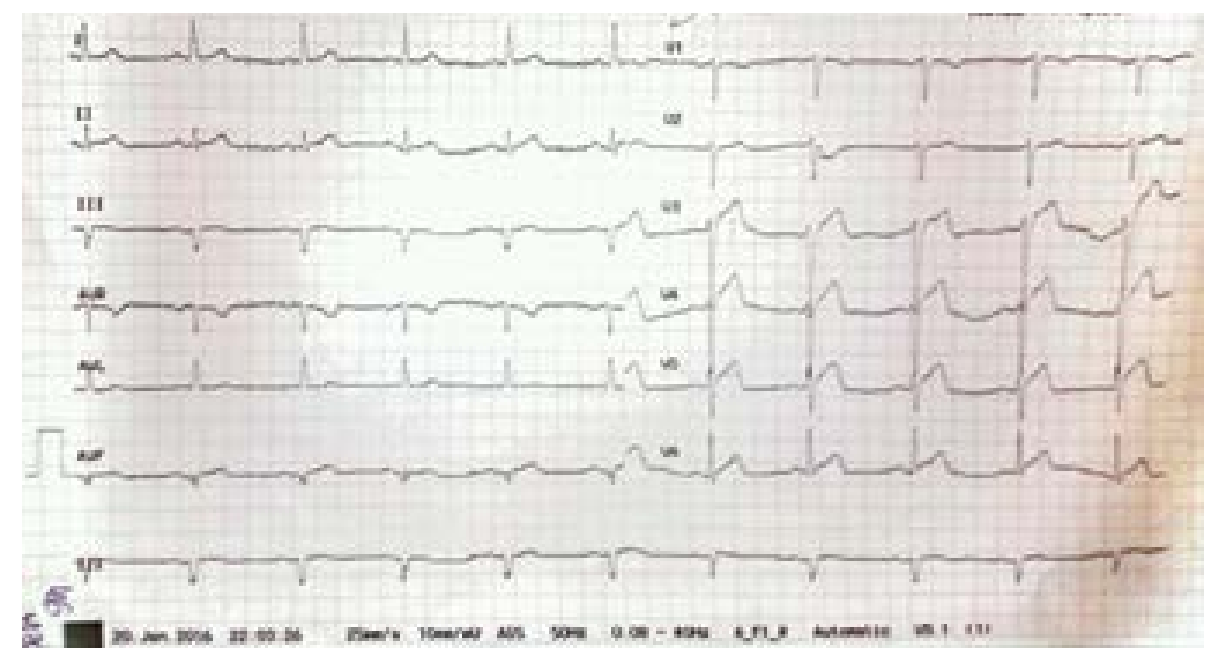

Rycina 2. Elektrokardiogram spoczynkowy przy przyjęciu do szpitala - uniesienie odcinka ST w odprowadzeniach V3-V6 
Ze względu na profil zmian lipidogramu u chorego, obciążonego bardzo wysokim ryzykiem sercowo-naczyniowym, w leczeniu hipolipemizującym zastosowano terapię skojarzoną inhibitorem reduktazy hydroksy-metyloglutarylokoenzymu A (HMG-CoA, hydroxy-methylglutaryl coenzyme A) - atorwastatyną (w dawce $40 \mathrm{mg} / \mathrm{d}$.) oraz fenofibratem (w dawce $160 \mathrm{mg} / \mathrm{d}$.). Wkrótce po zainicjowaniu skojarzonej terapii hipolipemizującej zaobserwowano wzrost aktywności aminotransferaz (aminotransferazy alaninowej [AIAT, alanine aminotransferase] do $177 \mathrm{j} / \mathrm{l}$, tj. wartości 3-krotnie przekraczającej górną granicę normy [ULN, upper limit of normal]). Zmodyfikowano dotychczasową terapię, odstawiając fibrat, a jako jedyny lek hipolipemizujący pozostawiając rosuwastatynę w dawce $15 \mathrm{mg} /$ dobę. W tym wyborze kierowano się potencjałem wchodzenia w interakcje z innymi stosowanymi lekami.

W kontrolnym badaniu echokardiograficznym, wykonanym w 7. dobie hospitalizacji, w koniuszku lewej komory stwierdzono balotującą skrzeplinę. Do dotychczasowego leczenia dołączono warfarynę (stosując pomostowo, do czasu ustabilizowania się wartości międzynarodowego wskaźnika znormalizowanego [INR, international normalized ratio], enoksaparynę) oraz zamieniono tikagrelor na klopidogrel w dawce $75 \mathrm{mg} /$ dobę.

Zważywszy na prawdopodobny zatorowy mechanizm zawału serca oraz stwierdzenie skrzepliny w lewej komorze serca wykonano wstępną diagnostykę w kierunku trombofilii. W wykonanych przesiewowych badaniach laboratoryjnych białek układu krzepnięcia nie stwierdzono istotnych zaburzeń (nieznacznie obniżone stężenie AT III - 71\% [norma 75-125\%]) oraz prawidłowe stężenia białek C, S i antykoagulantu toczniowego).

W ciągu 4 miesięcy od hospitalizacji pacjent wdrożył zasady postępowania niefarmakologicznego; schudł $10 \mathrm{~kg}$ i zwiększył aktywność fizyczną. Wartości ciśnienia tętniczego oraz glikemii na czczo pozostawały w granicach normy. Rozpoczęto terapię skojarzoną (rosuwastatyną w dawce $15 \mathrm{mg}$ oraz fenofibrat w dawce $215 \mathrm{mg}$ ). W kontrolnym badaniu lipidogramu po miesiącu stosowania wyżej opisanej terapii docelowe wartości cholesterolu frakcji LDL nadal nie zostały osiągnięte (wyjściowo, w 2004 r., stężenie tej frakcji cholesterolu wynosiło $150 \mathrm{mg} / \mathrm{dl}$, za cel terapii uznano < $70 \mathrm{mg} / \mathrm{dl}$ ); stężenie TG pozostawało podwyższone (tab. 1). Aktywności aminotransferaz pozostawały w normie (AIAT $25 \mathrm{j} . /$ I, aminotransferazy asparaginianowej [AspAT, aspartate aminotransferase] 23 j./I). Zwiększono dawkę rosuwastatyny do $40 \mathrm{mg}$. Kolejne kontrolne badanie wykazało, że cel pierwszorzędowy został osiągnięty (cholesterol frakcji $\mathrm{LDL}<1,8 \mathrm{mmol} / \mathrm{I}$ [< $70 \mathrm{mg} / \mathrm{dl}]$ ] [4]. Z kolei ze względu na utrzymywanie się wysokiego stężenia TG i podwyższonego stężenia cholesterolu nie-HDL (143 mg/dl - 30 = $113 \mathrm{mg} /$ /dl) u pacjenta zwiększono dawkę fenofibratu do $267 \mathrm{mg}$ i zalecono dalszą modyfikację diety.

\section{Omówienie}

We wszystkich grupach wiekowych pęknięcie blaszki miażdżycowej pozostaje główną przyczyną incydentów sercowo-naczyniowych, ale u młodych osób (< 45. rż.) częściej niż w starszych grupach wiekowych obserwuje się kliniczne cechy zawału przy braku istotnych zwężeń tętnic wieńcowych w koronarografii (ok. 20\%) [5]. Mechanizmami odpowiedzialnymi za zawał serca w takich przypadkach mogą być zator do naczynia wieńcowego, pierwotne i wtórne stany nadkrzepliwości (5\%), a także skurcz, zapalenie, uraz, wrodzone anomalie tętnic wieńcowych. U opisanego pacjenta najprawdopodobniej doszło do zamknięcia tętnicy wieńcowej w mechanizmie zatorowo-zakrzepowym. Brak zmian w innych naczyniach wieńcowych może także sugerować podobne tło poprzednich epizodów martwicy mięśnia sercowego. Również przebyty udar mózgu mógł przebiegać w mechanizmie zatoru i wtórnego ukrwotocznienia. Materiałem zatorowym wywołującym zawał serca może być skrzeplina, fragment blaszki miażdżycowej czy tkanki nowotworowej. Jedną z przyczyn powstawania skrzepliny w tętnicy wieńcowej w młodszych grupach wiekowych moga stanowić wrodzone (które u opisanego pacjenta wykluczono) i nabyte stany nadkrzepliwości (trombofilie).

Najczęstszy modyfikowalny czynnik ryzyka wystąpienia incydentów sercowo-naczyniowych, w każdej grupie wiekowej, to hipercholesterolemia. Z kolei nadrzędnym celem jej leczenia jest redukcja stężenia cholesterolu frakcji LDL. Podstawą postępowania niefarmakologicznego w prewencji incydentów sercowo-naczyniowych u pacjentów z dyslipidemią jest modyfikacja stylu życia, tj. zmniejszenie masy ciała poprzez zastosowanie odpowiedniego modelu żywienia oraz umiarkowana i regularna aktywność fizyczna, a także zaprzestanie palenia papierosów i utrzymywanie wartości ciśnienia tętniczego poniżej 140/90 mm Hg. Lekami z wyboru w farmakoterapii hipercholesterolemii są statyny, które hamują wątrobowe wytwarzanie cholesterolu i obniżają jego stężenie w surowicy krwi. Stosując statynę, można obniżyć stężenie cholesterolu frakcji LDL maksymalnie o około 55\%. W metaanalizie Boekholdta i wsp. [6] wykazano, że redukcji stężenia cholesterolu frakcji LDL poniżej $50 \mathrm{mg} / \mathrm{dl}$ towarzyszy zmniejszenie ryzyka wystapienia incydentów sercowo-naczyniowych o około 55\%. Ryzyko to, nawet po osiągnięciu niskich wartości cholesterolu frakcji LDL, przy podwyższonym stężeniu TG i niskim stężeniu cholesterolu frakcji HDL nie ulega całkowitej redukcji i pozostaje jako ryzyko rezydualne [4, 6-9]. Ryzyko rezydualne wiąże się z obecnością małych gęstych cząsteczek LDL, obniżonym stężeniem cholesterolu frakcji HDL $(<40 \mathrm{mg} / \mathrm{dl}$ u mężczyzn i $<45 \mathrm{mg} /$ dl u kobiet) oraz podwyższonym stężeniem TG (> 150 mg/dl) [2]. Dyslipidemia aterogenna najczęściej występuje jako składowa zespołu metabolicznego, który jest konstelacją wielu czynników ryzyka, w tym także: nadciśnienia tętniczego, zaburzeń gospodarki węglowodanowej 
(w tym cukrzycy typu 2), przewlekłego stanu zapalnego i prozakrzepowego. W otyłości, gdy tkanka tłuszczowa staje się dysfunkcyjna, następuje uwolnienie cytokin prozapalnych i prokoagulacyjnych do układu krążenia, co predysponuje do wystąpienia incydentów sercowo-naczyniowych [10]. U osób po przebytym incydencie sercowo-naczyniowym, obarczonych bardzo wysokim ryzykiem wystąpienia kolejnego epizodu sercowo-naczyniowego, obecnie zaleca się obniżenie stężenia cholesterolu frakcji LDL do mniej niż 1,8 mmol/I (< $70 \mathrm{mg} / \mathrm{dl}$ ) lub redukcję o co najmniej $50 \%$, jeśli wyjściowe stężenie wynosi między 1,8 i 3,5 mmol/l (70 i $135 \mathrm{mg} / \mathrm{dl}$ ) [11]. Każde obniżenie stężenia cholesterolu frakcji LDL o $1 \mathrm{mmol} / \mathrm{I}$ powoduje redukcję śmiertelności i chorobowości z powodu choroby układu sercowo-naczyniowego o 22-28\% [8]. Ponadto w wytycznych dotyczących postępowania w dyslipidemiach z 2016 roku zaznaczono, że cholesterol frakcji nie-HDL (wartość nie-HDL = stężenie cholesterolu całkowitego - stężenie cholesterolu frakcji HDL) stanowi rozsądny i praktyczny cel drugorzędowy leczenia (cel pierwszorzędowy to obniżenie stężenia cholesterolu frakcji LDL), ponieważ jego pomiar nie wiąże się z koniecznością pozostawania na czczo oraz nie wymaga, aby stężenie TG wynosiło mniej niż $4,5 \mathrm{mmol} / \mathrm{l}(<400 \mathrm{mg} / \mathrm{dl})[4,11]$. Drugorzędowe stężenia docelowe cholesterolu frakcji nie-HDL, wynoszące poniżej 2,6; poniżej 3,3 i mniej niż 3,8 mmol/l $(<100,<130 \mathrm{i}<145 \mathrm{mg} / \mathrm{dl})$, zaleca się u osób cechujących się ryzykiem, odpowiednio, bardzo wysokim, wysokim i niskim do umiarkowanego [11]. Stężenie cholesterolu frakcji nie-HDL pozwala lepiej oszacować ryzyko niż wartość cholesterolu frakcji LDL, szczególnie u chorych na cukrzycę, osób z hipertriglicerydemią oraz z przewlekłą chorobą nerek [4]. Kolejnym celem leczenia pacjenta z dyslipidemią aterogenną może być obniżenie stężenia TG. Wskazaniem (Ila, B) do rozpoczęcia farmakoterapii jest stężenie TG ponad $200 \mathrm{mg} / \mathrm{dl}$ [11]. U opisywanego pacjenta zastosowano skojarzone leczenie statyną z fibratem, co skutkowało wzrostem aktywności AIAT po 2 dniach terapii. Wzrost aktywności AIAT uznaje się za istotny, gdy 3-krotnie przekracza ULN. W wytycznych European Society of Cardiology (ESC) z 2016 roku dotyczących postępowania w dyslipidemiach zalecono diagnostykę schorzeń mogących przebiegać dotąd bezobjawowo (choroba stłuszczeniowa wątroby) i monitorowanie aktywności AIAT. W przypadku utrzymywania się podwyższonej aktywności AIAT należy odstawić stosowaną statynę, która może być ponownie zastosowana po normalizacji wskaźnika funkcji wątroby [11]. Normalizację podwyższonej aktywności transaminaz często można uzyskać, zmniejszając dawkę lub po zmieniając rodzaj statyny [8]. Atorwastatyna ulega początkowej biotransformacji w wątrobie, głównie przy udziale izoenzymu CYP 3A4, co powoduje, że w indywidualnych przypadkach jej stosowanie może się wiązać ze zwiększonym, w stosunku do rosuwastatyny, ryzykiem wzrostu aktywności transaminaz. Rosuwastatyna podlega modyfikacji wątrobowej w około 10\%, a głównymi izoenzymami biorącymi udział w jej metabolizmie są: CYP
2C9, w mniejszym stopniu CYP 2C19, CYP 3A4 i CYP 2D6. Stosując terapię skojarzoną, należy zwracać szczególną uwagę na możliwe interakcje między lekami stosowanymi w terapii pacjenta. Jeśli wzrost aktywności AIAT utrzymuje się ponad 3-krotnością ULN lub wzrasta w kolejnych oznaczeniach, to leczenie należy przerwać [8].

Przykład terapii hipolipemizującej opisanego pacjenta z jednej strony wskazuje, że przejściowy wzrost aktywności aminotransferaz nie nawraca mimo intensyfikacji leczenia statyną po przerwie, a z drugiej strony, że nawet skojarzona terapia hipolipemizująca statyną i fibratem nie zapewnia pełnej kontroli lipidogramu bez modyfikacji stylu życia, co zalecono opisanemu choremu.

Hipertriglicerydemia jest stanem sprzyjającym zaburzeniom układu hemostazy i nadkrzepliwości, a terapia fibratami może mieć korzystny wpływ na modyfikację tych zaburzeń. Nadkrzepliwość powinna być brana pod uwagę jako potencjalny czynnik ryzyka epizodów sercowo-naczyniowych u osób poniżej 50. roku życia z objawami zakrzepicy w układzie tętniczym, zwłaszcza jeśli nie są obecne najczęściej występujące czynniki ryzyka rozwoju miażdżycy [2]. Jednym z zaburzeń występujących w obrębie zespołu metabolicznego jest nadkrzepliwość [10, 12]. Udokumentowano ponadto, że podwyższone stężenie TG wiąże się ze zwiększeniem stężeń czynnika krzepnięcia VII, fibrynogenu i inhibitora aktywatora plazminogenu typu 1 (PAl-1, plasminogen activator inhibitor 1) oraz zwiększeniem lepkości krwi. Wysokie stężenie cholesterolu frakcji HDL współistnieje natomiast ze zmniejszoną agregacją płytek, niewielkim stężeniem PAl-1 i zmniejszeniem lepkości krwi [12, 13].

\section{Podsumowanie}

Opisany przypadek pacjenta z dyslipidemią aterogenną, po przebytych kilku incydentach sercowo-naczyniowych, stanowi przykład utrzymywania się podwyższonego ryzyka rezydualnego mimo stosowanej terapii hipolipemizującej i wstępnej modyfikacji trybu życia. U pacjentów z dyslipidemią aterogenną podwyższone stężenie TG oraz obniżone stężenie cholesterolu frakcji HDL, łącznie z innymi zaburzeniami wynikającymi z obecności zespołu metabolicznego, synergistycznie zwiększają ryzyko, nawet w przypadku osiągnięcia docelowego stężenia cholesterolu frakcji LDL [4]. Przy czym u chorych tych można rozważyć inny niż przy hipercholesterolemii mechanizm incydentów sercowo-naczyniowych, na przykład stan nadkrzepliwości, jak w przedstawionym przypadku. W terapii zaburzeń lipidowych należy uwzględniać zarówno poziom ryzyka, jak i możliwość wystąpienia interakcji lekowych utrudniających proces leczenia. Zgodnie z zaleceniami ekspertów powinno się dostosowywać terapię, dążąc do osiągnięcia docelowych wartości cholesterolu frakcji LDL i TG w sposób umożliwiający unikanie powikłań, intensyfikując jednocześnie składowe postępowania niefarmakologicznego [11]. 


\section{Abstract}

We present a medical case of a patient with atherogenic dyslipidemia who experienced a new cardiovascular episode despite lipid-lowering therapy. This is an example of a residual risk that remains even after reaching target level of LDL-cholesterol.

Key words: atherogenic dyslipidemia, residual risk

\section{Piśmiennictwo}

1. World Health Organization Regional Office for Europe. Mortality indicator database: mortality indicators by 67 causes of death, age and sex (HFA-MDB). Update: December 2015. Available on: data.euro.who.int/ /hfamdb/. Data access: December 29, 2015.

2. Cybulska B, Szostak WB, Kłosiewicz-Latoszek L. Zapobieganie chorobom układu krążenia. In: Szczeklik A. ed. Choroby wewnętrzne. Wydawnictwo Medycyna Praktyczna, Kraków 2010: 148-150.

3. Wożakowska-Kapłon B, Filipiak K, Mamcarz A, et al. Aktualne problemy terapii dyslipidemii w Polsce - II Deklaracja Sopocka. Stanowisko grupy ekspertów wsparte przez Sekcję Farmakoterapii Sercowo-Naczyniowej Polskiego Towarzystwa Kardiologicznego. Kardiol Pol. 2014; 72(9): 847-853, doi: 10.5603/kp.2014.0182, indexed in Pubmed: 25231425.

4. Szymański FM, Filipiak KJ, Wożakowska-Kapłon B, et al. Dyslipidemia aterogenna w codziennej praktyce - interdyscyplinarny konsensus polskich ekspertów. Folia Cardiol. 2016; 11: 1-16.

5. Dobrowolska E, Trzos E, Plewka M. Czynniki ryzyka zawału serca u młodych osób. Forum Kardiol. 2002; 7: 79-81.

6. Boekholdt SM, Hovingh GK, Mora S, et al. Very low levels of atherogenic lipoproteins and the risk for cardiovascular events: a meta-analysis of statin trials. J Am Coll Cardiol. 2014; 64(5): 485-494, doi: 10.1016/j.jacc.2014.02.615, indexed in Pubmed: 25082583.
7. Idzior-Waluś B, Waluś-Miarka M. Na czym polega postęp w leczeniu dyslipidemii w cukrzycy? Co z badaniem ACCORD? Diabetol Prakt. 2011; 12: 1-5.

8. Wożakowska-Kapłon B, Barylski M, Salwa P, et al. Zalecenia postępowania w dyslipidemii - propozycje algorytmu dla lekarzy rodzinnych. Forum Med Rodz. 2012; 6: 261-282.

9. Starzyk K, Wożakowska-Kapłon B. Gdy statyna to za mało - skojarzenie statyny $z$ ezetimibem $w$ terapii hipercholesterolemii. Folia Cardiol. 2016; 10(6): 428-437, doi: 10.5603/fc.2015.0081.

10. Grundy SM, Grundy SM. Adipose tissue and metabolic syndrome: too much, too little or neither. Eur J Clin Invest. 2015; 45(11): 1209-1217, doi: 10.1111/eci.12519, indexed in Pubmed: 26291691.

11. Catapano AL, Graham I, De Backer G, et al. Authors/Task Force Members, Additional Contributor. 2016 ESC/EAS Guidelines for the Management of Dyslipidaemias. Eur Heart J. 2016; 37(39): 2999-3058, doi: 10.1093/eurheartj/ehw272, indexed in Pubmed: 27567407.

12. Marckmann P. Dietary treatment of thrombogenic disorders related to the metabolic syndrome. Br J Nutr. 2000; 83 Suppl 1: S121-S126, indexed in Pubmed: 10889802.

13. Fruchart JC, Davignon J, Hermans MP, et al. Residual Risk Reduction Initiative (R3i). Residual macrovascular risk in 2013: what have we learned? Cardiovasc Diabetol. 2014; 13: 26, doi: 10.1186/14752840-13-26, indexed in Pubmed: 24460800. 